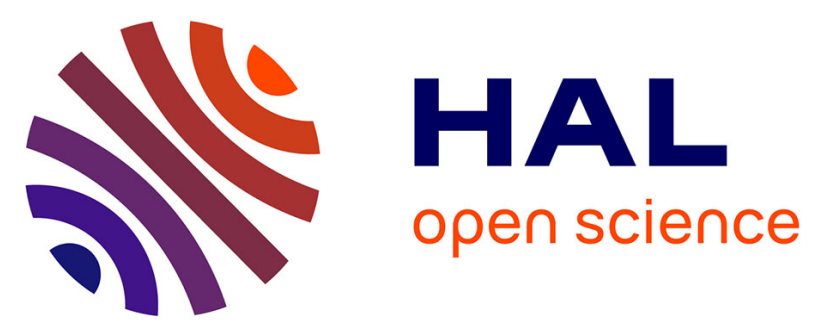

\title{
Social Skills Training Tool in Virtual Reality, Intended for Managers and Sales Representatives
}

Jean-Daniel Taupiac, Nancy Rodriguez, Olivier Strauss, Pierre Beney

\section{To cite this version:}

Jean-Daniel Taupiac, Nancy Rodriguez, Olivier Strauss, Pierre Beney. Social Skills Training Tool in Virtual Reality, Intended for Managers and Sales Representatives. IEEE-VR 2019 - 26th Conference on Virtual Reality and 3D User Interfaces, Mar 2019, Osaka, Japan. , pp.1183-1184, 2019, 10.1109/VR.2019.8798317 . hal-02091017

\section{HAL Id: hal-02091017 https://hal.science/hal-02091017}

Submitted on 5 Apr 2019

HAL is a multi-disciplinary open access archive for the deposit and dissemination of scientific research documents, whether they are published or not. The documents may come from teaching and research institutions in France or abroad, or from public or private research centers.
L'archive ouverte pluridisciplinaire HAL, est destinée au dépôt et à la diffusion de documents scientifiques de niveau recherche, publiés ou non, émanant des établissements d'enseignement et de recherche français ou étrangers, des laboratoires publics ou privés. 


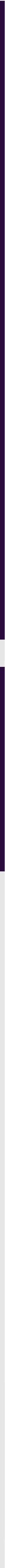

\section{PROTOTYPE}

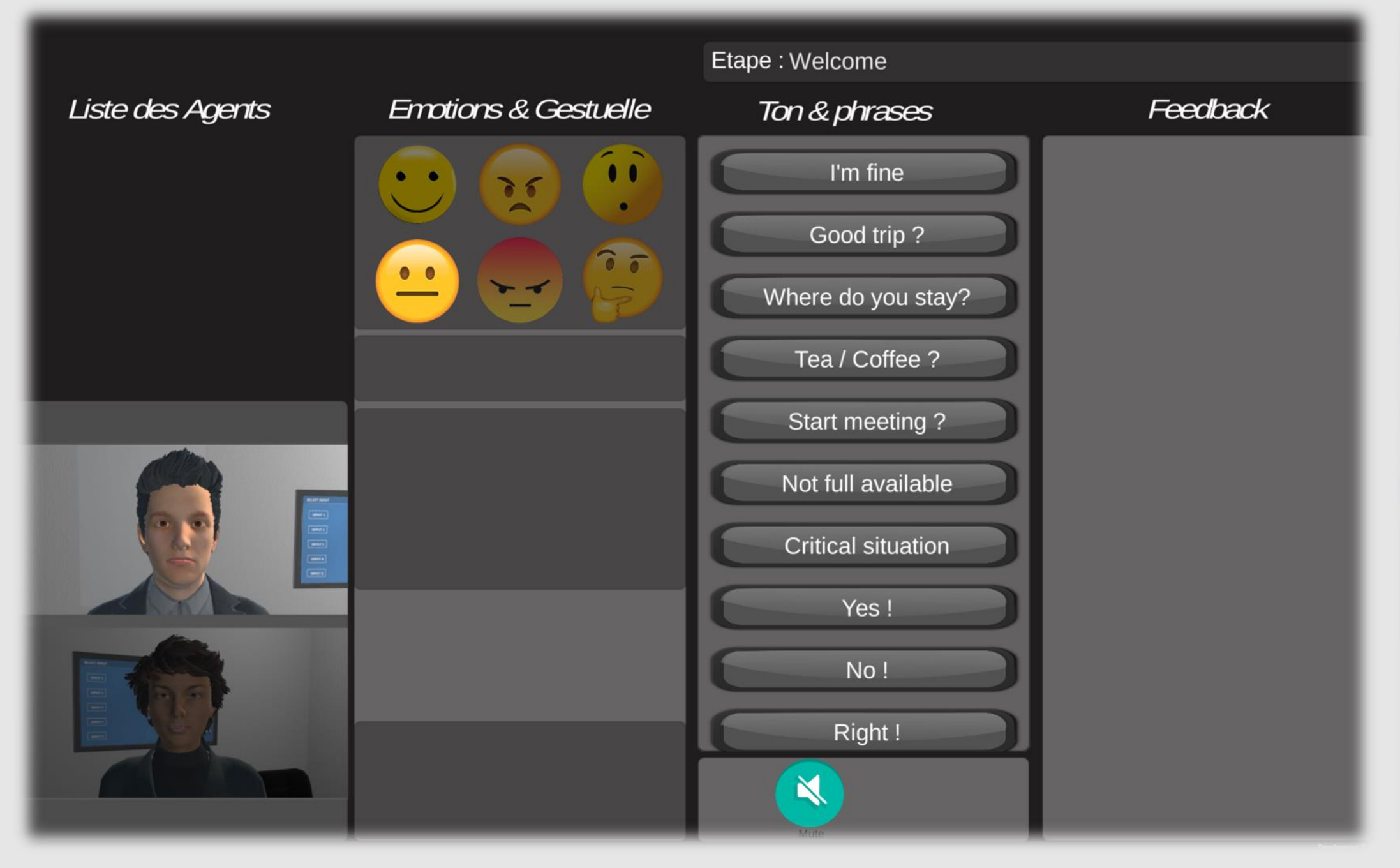

"Wizard of Oz" control panel

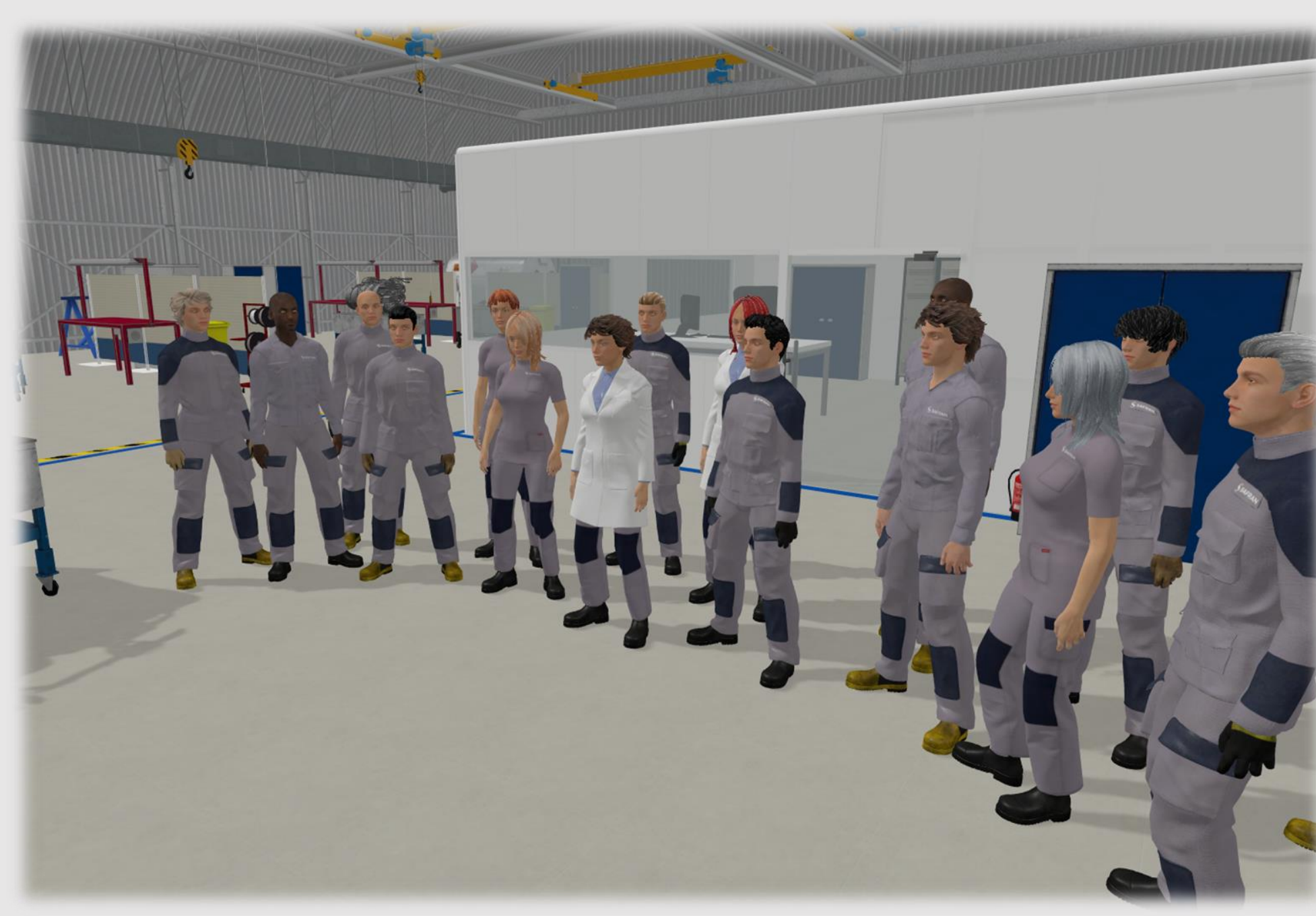

Managers' scene

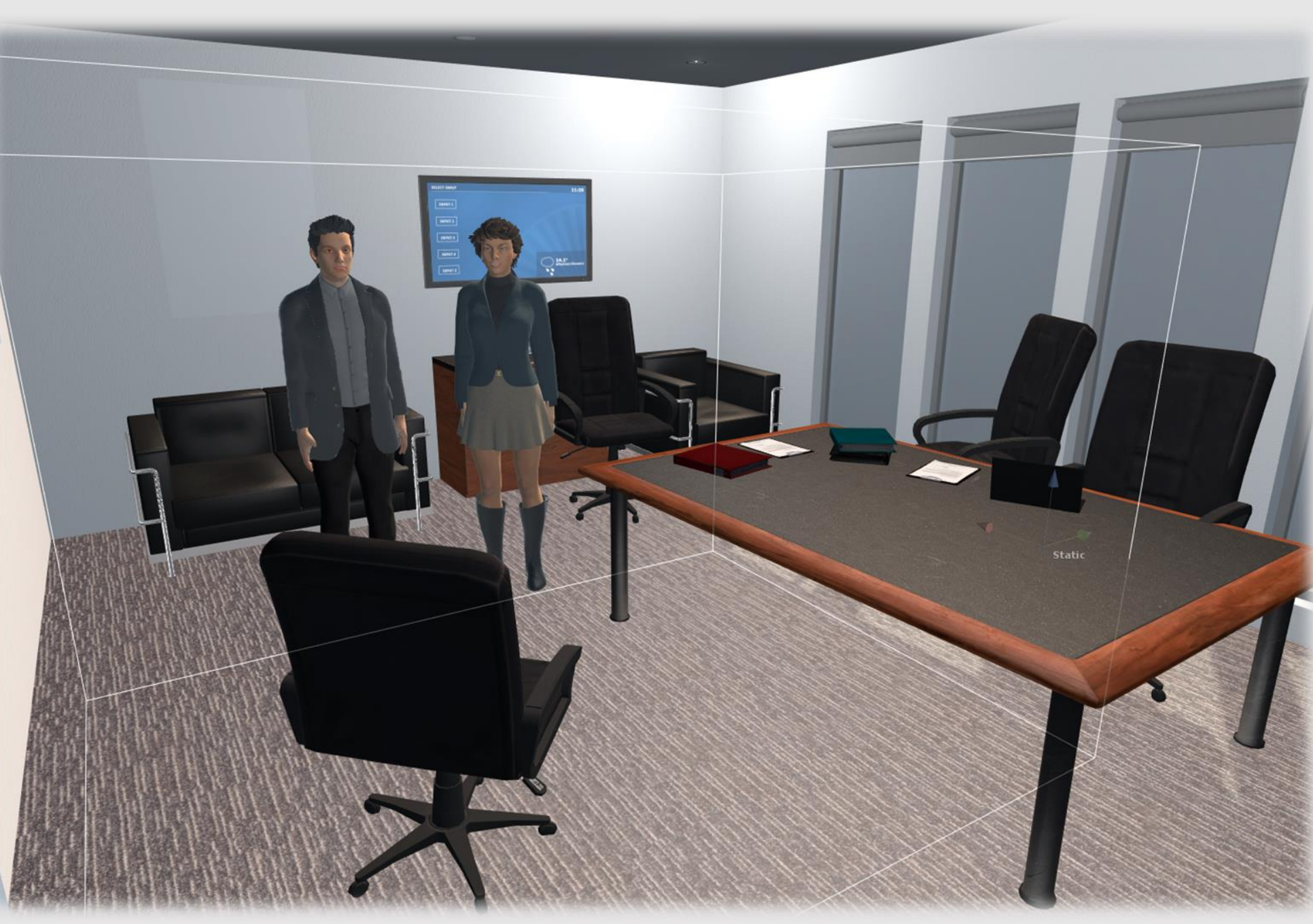

Sales representatives' scene

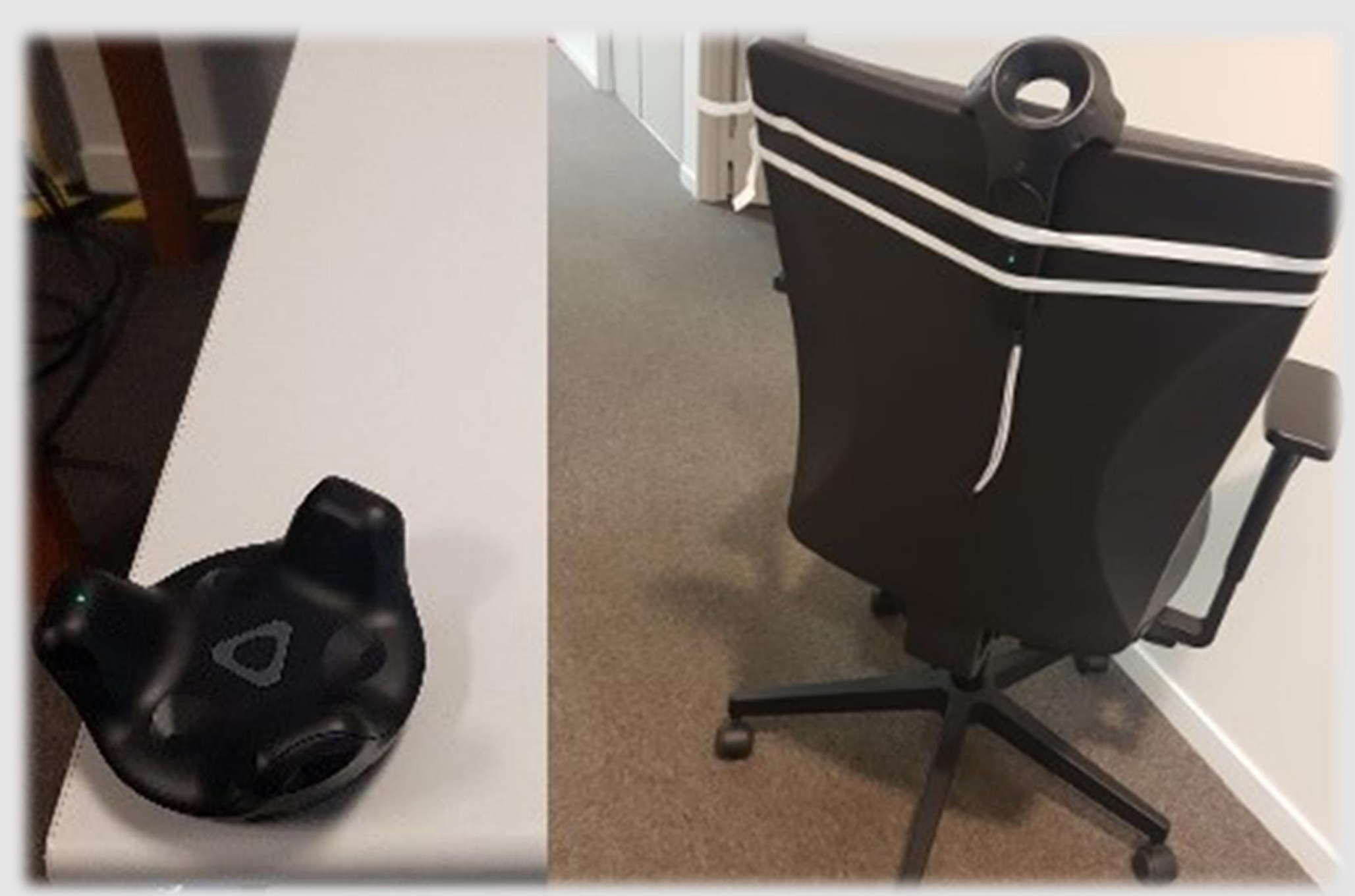

Real objects tracking

\section{EXPERIMENTS}

To validate

How users feel social interaction?

How users feel present in the virtual environment?

Generic scenario: restaurant-choice negotiation

$>$ Reuse of sales representatives' scene

$>$ With a single virtual character $\rightarrow$ same gender

口 Process:

1. Prototype test

2. IPQ presence questionnaire [16]

3. Social presence questionnaire [17]

4. Open interview

54 co-workers:

$63 \%$ men, $37 \%$ women

$>$ Average age: $36( \pm 10)$

\section{CONCLUSIONS}

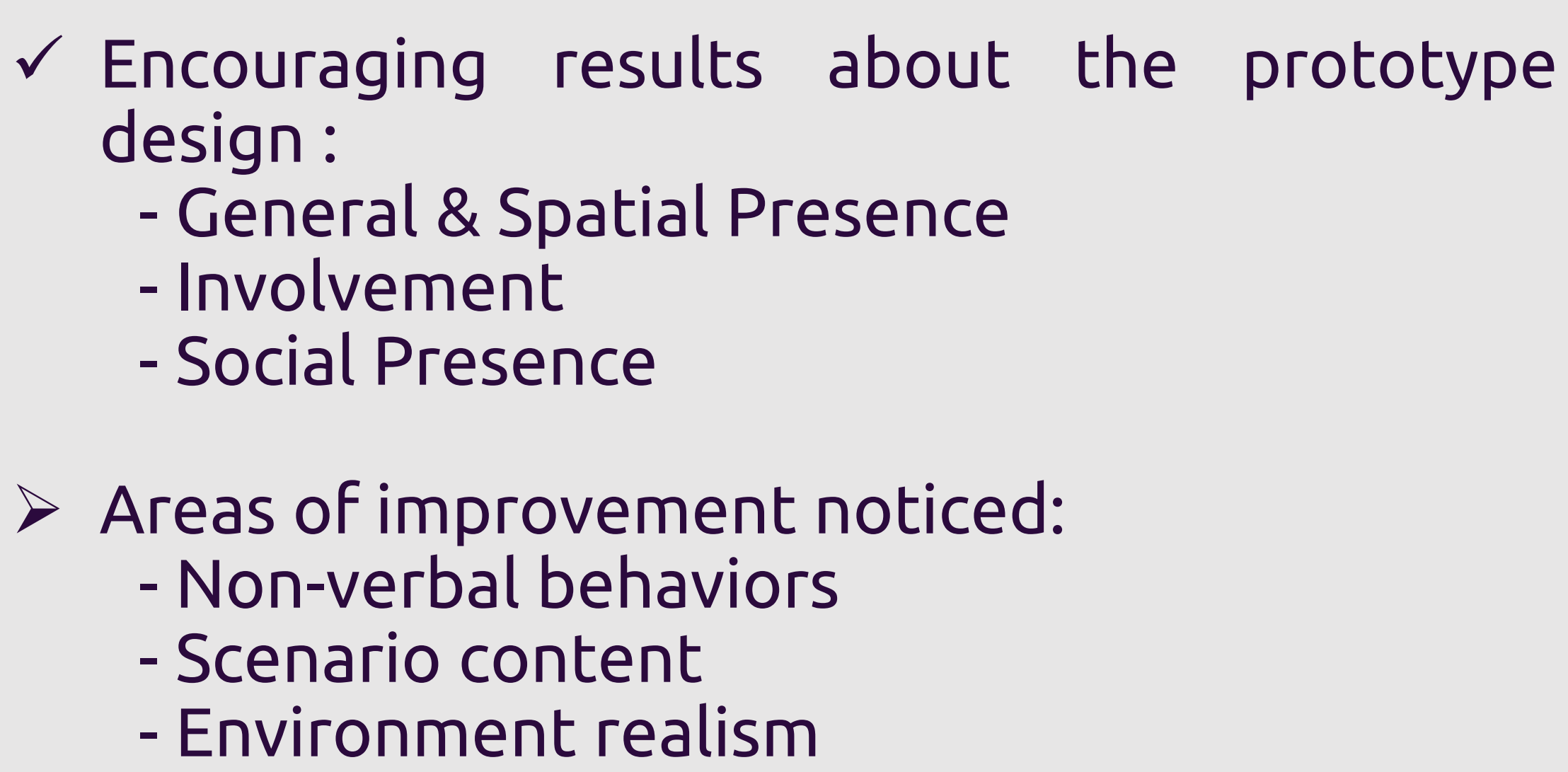

\section{RESULTS}

